\title{
Evaluation of the Impact of Anthropogenic Activities on the Microbiological Quality of Azumini Odumanya Stream, Port Harcourt, Nigeria
}

\author{
Obire, Omokaro, Douglas, Salome Ibietela*, and Chuku, Jennifer Ibuchim
}

Department of Microbiology, Rivers State University, Nkpolu-Oroworukwo, P. M. B. 5080, Port Harcourt, Rivers State, Nigeria

*Corresponding author

\section{Keywords}

Anthropogenic Activities, Azumini Odumaya Stream, Coliforms, E. coli, Pathogens

Article Info

Accepted: 12 June 2021 Available Online: 10 July 2021
The quality of any surface water body is a function of either or both natural influences and human activities going on around the environment. The Azumini Odumaya stream in Obio/Akpor Local Government Area of Rivers State was evaluated for its Microbiological quality. Forty (40) water samples were aseptically collected from five designated Stations along the stream, for a period of four (4) months using sterile bottles and transported to the Microbiology laboratory. Microbiological analyses were carried out using standard microbiological methods. The following culture media were used: Nutrient agar, Eosin methylene blue, MacConkey, Salmonella-Shigella, Thiosulfate-citrate bile salts sucrose agar, Centrimide agar and Sabouraud dextrose agar. Bacterial isolates were characterized using biochemical techniques while the fungal isolates were characterized macroscopically and microscopically. The total heterotrophic bacterial counts, Vibrio counts, Salmonella-Shigella counts, total coliform counts, feacal coliform counts, and Pseudomonas counts of the water samples ranged from: $5.32 \times 10^{6} \pm 0.63$ to $9.21 \times 10^{6} \pm 6.71,2.39 \times 10^{3} \pm 1.8$ to $1.15 \times$ $10^{4} \pm 1.97,1.68 \times 10^{4} \pm 1.84$ to $2.88 \times 10^{4} \pm 1.49,2.02 \times 10^{4} \pm 1.48$ to $6.4 \times 10^{4} \pm$ $1.63,1.89 \times 10^{4} \pm 1.56$ to $8.9 \times 10^{4} \pm 1.08,0$ to $3.9 \times 10^{2} \pm 1.43$ and $3.3 \times 10 \pm 0.83$ to $1.11 \times 10^{2} \pm 1.4 \mathrm{CFU} / \mathrm{ml}$, respectively. The bacterial isolates identified from the various Stations include: Bacillus sp, Staphylococcus sp, Pseudomonas sp, Salmonella sp, Vibrio sp, Klebsiella sp, Enterobacter sp, Providencia sp. and E. coli. The fungal counts ranged from $3.3 \times 10 \pm 0.83$ to $1.11 \times 10^{2} \pm 1.4 \mathrm{CFU} / \mathrm{ml}$. Fungal isolates identified include: Pencillium chrysogenium, Aspergillus niger, Fusarium solani, Mucor sp, Rhizopus sp and Candida albicans. The bacterial populations were very high and the detectable faecal coliform counts were also very high. The presence of $E$. coli which is an indicator of faecal contamination confirms that the stream is faecally contaminated which is also an indication of possible contamination with pathogenic bacteria. Many of the bacterial isolates are potential pathogens which are associated with gastroenteritis and other forms of bacterial infections. These findings indicate public health hazards if the water is used for domestic purposes without any form of treatment. 


\section{Introduction}

Water is a basic natural resource for sustaining lives on earth and though, this resource is very abundant on the earth it is not immediately available to the teaming human, animal, and agro-plant population all over the world (UNDSEA, 2001). Besides, where water is available or abundant on earth, its quality is also a serious source of concern and this is more so, against the backdrop that the quality of water anywhere in the world is subject to natural, geographical, human activities and environmental factors (UNDSEA, 2001; Okpokwasili et al., 2013). According to Meybeck et al., (1996) water quality is said to be defined in terms of the chemical, physical, and biological characteristics of water, in respect to its suitability for an intended purpose.

Water from rivers, streams, lakes, ponds, etc., are normally used as sources of water supply for domestic, agricultural and industrial purposes (William, 1997). Human activities of various kinds are considered to be the sources of pollution, producing highly poisonous wastes such as chemicals and human wastes including faeces. Faeces may contain pathogenic microbes that can cause many illnesses ranging from typhoid fever, cholera and bacillary dysentery to minor respiratory and skin diseases (Obire and Aguda, 2002). In most developing countries including Nigeria, there is indiscriminate act of dumping untreated waste into nearby rivers and streams which lowers the standards of health in the Niger Delta region (Inane et al., 1998). This is caused by a general lack of awareness of good hygiene practices, direct contamination of beach waters through bathing and washing, and uncontrolled waste disposal around the shoreline (Obire et al., 2002). Direct dumping of untreated or raw municipal and industrial effluent into rivers and lakes could contribute to microbial pollution, have a negative effect on the quality of water such as nutrient enrichment and deterioration, destruction of spawning grounds for aquatic and marine life, general fish kill and drinking use (Inane et al., 1998).

The water quality of rivers, streams and lakes changes with the seasons and this has profound influence on the population density of aquatic plants and animals (Lawson, 2011; Adeyemo et al., 2008). The geography and the topography of an area can also affect the quality of water in that area. Human activities, natural processes e.g. erosion, weathering, geochemical and geological characteristics of the environment as well as the ever-increasing population of the world have kept changes in natural water bodies constant (Arain et al., 2008; Adefemi and Awokunmi, 2010; Nduka, 2008; Bellingham, 2012). As a result, physical, chemical and biological parameters that influence water quality keep changing. Therefore, it is necessary to carry out regular quality monitoring of water bodies to ascertain these changes from time to time (Arain et al., 2008). The evaluation of microbiological and physicochemical quality of water bodies is aimed at establishing the safety of water bodies for human use. The Azumini-Odumaya stream is a vital source of water for washing of most of the market products, especially agricultural products purchased from the Rumuokoro market, for bathing (recreational activity), for fishing at some point and washing of cars. Thus, this study is aimed at evaluating the microbiological quality of the Azumini-Odumanya Stream.

\section{Materials and Methods}

\section{Description of Study Area}

The area under study is Azumini-Odumaya, a stream located in Rumuodumaya Community in Obio-Akpor Local Government Area of Rivers State in the Niger Delta Region of 
Nigeria. The coordinates are $4^{\circ} 52^{\prime} 10^{\prime \prime} \mathrm{N}$ and 6 59 '55"E. The Local Government Area covers $260 \mathrm{~km}^{2}$ and at the 2006 Census had a population of 464,789 . The principal livelihood of people from this area is farming, fishing, hunting, and trading. Although some of these activities are almost out of scene because of the influx of foreigners and development. Streams in this area especially the Azumini-Odumaya stream empties into other surrounding rivers such as: the Ntawoba creek and New Calabar River. The stream is also used for recreational activities such as swimming and fishing. Dumping of refuse by traders, open defaecation, washing of clothes, cars, processing of poultry meat and emptying of animal materials into the streams, release of untreated waste water from slaughter house into the stream, etc are some common activities that go on there. The map of the area under study is illustrated in Figure 1.

\section{Collection of water sample}

The water samples were collected in sterile bottles from five (5) different Stations along the stream. Samples were stored in box containing ice packs and were quickly transferred to the Microbiology Laboratory in the Department of Microbiology, Rivers State University.

\section{Enumeration and Isolation of Bacteria and Fungi in the Samples}

Water samples from the different Stations were analyzed using standard microbiological methods. Ten-fold dilutions were carried out serially to achieve a dilution of $10^{-4}$. After dilutions, aliquots of $0.1 \mathrm{ml}$ from $10^{-2}$ and $10^{-4}$ dilutions were plated out on already prepared nutrient agar plates in duplicate so as to estimate and isolate the total heterotrophic bacteria (Prescott et al., 2002). Aliquots $(0.1 \mathrm{ml})$ from $10^{-2}$ and $10^{-4}$ dilutions were plated out on MacConkey agar plates, Eosin
Methylene blue agar, Salmonella-Shigella agar plates, and Thiosulfate-citrate-bile salts sucrose agar plates for the isolation of faecal coliforms, Salmonella-Shigella and Vibrio spp., respectively. Plates which have been seeded with the samples were spread uniformly using a sterile bent glass rod, before they were incubated at $37{ }^{\circ} \mathrm{C}$ for 24 hours (Cheesbrough, 2005). An aliquot of $0.1 \mathrm{ml}$ from $10^{-2}$ and $10^{-3}$ dilutions were aseptically inoculated on freshly prepared Sabouraud dextrose agar plates to which antibiotic (50mg/ml streptomycin) was added to inhibit the growth of bacteria, while allowing the growth of fungi (Harrigan and McCance, 1990). The inoculums were spread using sterile bent glass rod on the SDA plates and plates incubated at $27^{\circ} \mathrm{C}$ for 5 to 7 days. After incubation, plates were read by counting the colonies on each plate, so as to achieve the bacterial and fungal load, while discrete colonies on the plates were sub-cultured unto freshly prepared nutrient and Sabouraud Dextrose agar plates. Continued sub-culturing was carried out until isolates were pure and void of contaminant. The pure cultures were stored in McCartney bottles containing $3 \mathrm{ml}$ of sterile $10 \% \mathrm{v} / \mathrm{v}$ glycerol suspension. The isolates were maintained frozen in the fridge at $-4^{\circ} \mathrm{C}$ (Amadi et al., 2014), until required for further analyses.

\section{Characterization and Identification of Bacterial and Fungal Isolates}

Bacterial isolates were characterized using cultural methods as described by Cheesbrough (2005). The biochemical identification methods used were Gram staining, sugar fermentation tests, oxidase, indole, methyl red, Voges Proskauer, citrate utilization, motility, catalase, starch hydrolysis, and coagulase test. The isolates were identified based on their cultural and biochemical properties comparing with known taxa using Bergey's Manual of Determinative Bacteriology (Holt et al., 
1994). Pure cultures of the fungi were subjected to macroscopic examination by observing the colony morphology, pigmentation, surface appearance and texture. Microscopic examinations of the fungal isolates were done using their wet mounts with lactophenol-cotton blue and reference made to a fungal identification atlas (Barnett and Hunter, 1992).

Evaluation of Total and Feacal Coliform Using the Most Probable Number (MPN) Method

The most probable number counts of the water samples were evaluated using the multiple tube method. There are three steps involved in this method: the presumptive test, the confirmed test and the completed test (Cheesbrough, 2005). In the presumptive test, fifteen test tubes of lactose broth of which the first five represent double strength and the other ten tubes represented the single strength were prepared. All the tubes contained inverted Durham's tube and they were sealed with cotton wool before they were autoclaved at $121^{\mathrm{O}} \mathrm{C}$ for 15 minutes of $15 \mathrm{psi}$. On cooling, $10 \mathrm{ml}$ of the water sample were inoculated into the tube labelled double strength, $1 \mathrm{ml}$ of water sample was transferred into the first five tubes of the single strength and finally $0.1 \mathrm{ml}$ of the water sample was transferred into the last set of test tubes labelled single strength. Tubes were incubated for two days and were checked for acid and gas production. Tubes which had acid and gas were recorded and using a wire loop, tubes with positive results were inoculated onto already prepared (sterile) lactose broth. This was incubated for 24 hours at $37^{\circ} \mathrm{C}$. In the completed test, tubes which had gas were streaked on prepared Eosin Methylene blue agar plates. This was to ascertain if the organisms that produced gas are coliforms (E. coli). E. coli on Eosin Methylene blue agar plate have a greenish metallic sheen appearance while Enterobacter sp appeared as large round deep pink colouration. Though further biochemical tests as well as microscopy was carried out to differentiate the organisms. The MPN was ascertained by comparing the tubes with gas production to the standard MPN chart (Cheesbrough, 2005).

\section{Statistical Analysis}

The results from this study were subjected to statistical analysis using the computer based program SPSS, version 22. Analysis of variance (ANOVA) and significance of mean differences were determined at $\mathrm{p}>0.05$.

\section{Results and Discussion}

The results for the microbial populations of the five Stations along the stream in $\log _{10} \mathrm{CFU} / \mathrm{ml}$ are presented in Table 1. The total heterotrophic bacterial counts of the Stations ranged from $6.43 \pm 0.63$ to $6.74 \pm 0.54$ $\log _{10} \mathrm{CFU} / \mathrm{ml}$, and Stations 3 had the highest load of total heterotrophic bacterial counts, while Station 1 had the least counts of total heterotrophic bacteria. This observation may be due to the location of Station 1, which is upstream of the other points with very few houses, more bushes, more of fishing activities than other human activities happen at this Station. The Vibrio counts ranged from $1.58 \pm 1.8$ to $2.92 \pm 1.17 \log _{10} \mathrm{CFU} / \mathrm{ml}$ with Station 1 having the least counts while Station 2 had the highest Vibrio counts. The mean value for total Salmonella-Shigella counts were $2.96 \pm 1.84, \quad 3.27 \pm 1.45, \quad 3.90 \pm 0.71$, $3.42 \pm 1.49$ and $3.44 \pm 1.48 \log _{10} \mathrm{CFU} / \mathrm{ml}$, for Stations 1, 2, 3, 4 and 5, respectively with Station 3 having the highest counts while Station 1 had the lowest counts. The high microbial counts observed in Station 3 may be due to the activities from the fish farms (release their untreated waste water directly into the stream) and other domestic waste discharged. There was no significant 
difference between the counts in the Stations ( $>>0.05$ ). The faecal coliform counts ranged from $3.56 \pm 1.48$ to $3.97 \pm 1.65 \log _{10} \mathrm{CFU} / \mathrm{ml}$. The coliform counts ranged from $3.72 \pm 1.56$ to $4.45 \pm 0.76 \quad\left(\log _{10} \mathrm{CFU} / \mathrm{ml}\right)$, while the Pseudomonas counts were $1.10 \times 10^{2} \pm 1.00$, $0.59 \pm 1.23, \quad 0.62 \pm 1.31, \quad 0.35 \pm 1.06$, $0.82 \pm 1.43 \log _{10} \mathrm{CFU} / \mathrm{ml}$ for Stations 1, 2, 3, 4 and 5 , respectively. The total heterotrophic bacterial counts in this study were above the permissible limit of $1.0 \times 10^{2} \mathrm{CFU} / \mathrm{ml}$ which is a standard limit of heterotrophic bacterial counts for drinking water (EPA, 2003). According to Bartram et al., (2003), Significant changes in heterotrophic bacterial counts serve as an alert for possible deterioration of water quality, triggering further investigation. Obire and Osigwe, (2016) in a previous study had reported high values of total heterotrophic bacterial and coliform counts which agreed with this current study. Douglas and Isor (2015) also reported high total heterotrophic bacterial counts ranging from $2.2 \times 10^{4}$ to $2.5 \times 10^{7} \mathrm{CFU} / \mathrm{ml}$ in pond water in Ogoni land.

Moreover, the recommended total coliform and faecal coliform level is 0 to 10 coliforms and zero (0) coliform, respectively (WHO, 2009). Thus, the total and faecal coliform counts of the Stream in this current study exceed the recommended limit. The fungal counts ranged from $3.3 \times 10 \pm 0.83$ to $1.11 \times 10^{2} \pm 1.4 \mathrm{CFU} / \mathrm{ml}$. Station $1 \mathrm{had}$ fungal counts of $3.3 \times 10 \pm 0.83$, Station $24.4 \times 10 \pm 1.53$, Station $3 \quad 1.11 \times 10^{2} \pm 1.4, \quad$ Station 4 $3.3 \times 10 \pm 0.83$, and Station 5; $8.8 \times 10 \pm 1.89$ $\mathrm{CFU} / \mathrm{ml}$. There was no significant difference in the counts between the sampling Stations at ( $>0.05$ ). Fungal isolates identified include: Pencillium chrysogenium, Aspergillus niger, Fusarium solani, Mucor sp, Rhizopus sp and Candida albicans.

It is expected that water samples contaminated with coliform should be evaluated for $E$. coli detection or other coliforms so as to ascertain if the water is contaminated with human or animal waste (EPA, 2003). The high values of faecal coliforms in this study could be attributed to the impact posed by human activities inside or close to the stream such as; direct discharge of untreated human waste into the water body. This was observed especially by some residence that live by the stream, which channeled their untreated sewage directly into the stream, release of animal waste from farms and direct disposal of domestic waste. Other possible sources of contamination could be attributed to run-off from waste dump sites around the Stream.

The detection of Shigella, Salmonella, and Vibrio spp in the Stream could be a course for alarm since they are of public health significance as they are mostly associated with gastrointestinal infections such as diarrhea, dysentery and other forms of infections (EPA, 2003). Other bacteria isolated from the water samples were: Serratia sp, Proteus sp, Providencia sp, Streptococcus sp, Enterobacter sp, Staphylococcus sp, Bacillus sp, Pseudomonas sp, Escherichia coli and Klebsiella sp and could also pose public health threat. Douglas and Isor, (2015) also identified the following bacteria from their studies: Escherichia coli, Bacillus, sp, Pseudomonas $\mathrm{sp}$, Proteus sp, Salmonella sp, Shigella sp, Streptococcus sp, Staphylococcus sp, Enterobacter sp and Micrococcus sp.

Figure 2 shows the percentage occurrence of organisms from the various Stations, during the sampling period. Thirteen (13) bacterial genera were identified with frequency of occurrence of Pseudomonas species 13\%, while Shigella and Vibrio species were $11.8 \%$. The rest are in this order; Salmonella species $5.9 \%$, E. coli 12\%, Klebsiella species 5.9\%, Providencia species 4.4\%, Serratia species $1.5 \%$, Bacillus species 13.2\%, Staphylococcus species 10.3\%, Proteus species 5.9\%, Streptococcus species $2.9 \%$ and Enterobacter 
spp 1.4\%. Bacillus sp had the highest frequency of occurrence in all water samples and in all the Stations sampled. This may be due to their spore forming ability that also enables them to tolerate hash environmental conditions for a long time.

Six fungal genera were identified from this study and the frequency of occurrence recorded for the fungi is as follows: Aspergillus niger 20\%, Penicillium chrysogenium 21\%, Rhizopus sp 17\%, Mucor sp and Fusarium solani 15\%, while Candida albicans is $12 \%$. Highest frequency of occurrence was recorded for Penicillium chrysogenium at $21 \%$, while the least was recorded for Candida albicans at $12 \%$. The distribution of the frequency of occurrence in fungi is shown in Figure 3. Penicillium and Aspergillus spp had the highest populations. These organisms produce large number of spores and get into the environment through dead plant materials. Douglas (2015) also observed similar fungal species from pond water samples in the Niger Delta. From that study, Aspergillus sp had the highest frequency of occurrence while Trichoderma $\mathrm{sp}$ had the least frequency of occurrence. The Trichoderma sp was not identified from this present study. The following fungal species were also predominant in the pond water: Penicillium sp, Aspergillus niger, Fusarium $\mathrm{sp}$, Aspergillus fumigatus, Rhizopus sp, Mucor sp, Aspergillus flavus, and Candida sp.

The distribution of bacteria isolated in the various sampling Stations is illustrated in Table 2. E. coli was present in all the 5 Stations. This could be attributed to the high level of feacal matter that is discharged into the water. Pseudomonas spp were also present in all Stations. This may be due to their wide range of metabolic and physiological characteristics that enables them to adapt to various environment conditions (Douglas and Amuzie, 2015). Serratia spp. was present only in Station 3. Proteus spp., Vibrio spp.,
Shigella spp., Salmonella spp., Providencia spp., Bacillus spp., Klebsiella spp., Staphylococcus spp., and Streptococcus spp., were present in all the 5 Stations sampled.

The presence of $E$. coli in water indicates contamination of the water with other enteric microbes which could be pathogenic (Prescott et al., 2002).

Table 3, showed the results of faecal coliforms using the most probable number. The sampling reference measures up to 1600 viable coliform counts which were most static for the $9^{\text {th }}$ samplings in Station 5. The MPN Index is per $100 \mathrm{ml}$ so for Station 1, sample 1, 2, 3 were most turbid with coliform counts of $>1600 \mathrm{MPN}$ Index/100ml. Thirty-four MPN Index per $100 \mathrm{ml}$ (34 MPN index/100ml) coliform counts were recorded for samples 4 and 5, While for Station 1 (control), $100 \mathrm{MPN}$ Index $/ 100 \mathrm{ml}$ were recorded for the $6^{\text {th }}$ and the $9^{\text {th }}$ sampling implying least presence of feacal coliforms.

The same trend was recorded in Station 2. Samples 1, 2, 3, 6 had the same dense population of $>1600 \mathrm{MPN}$ Index/100ml and recorded the least number $(12 \mathrm{MPN} / 100 \mathrm{ml})$ at $7^{\text {th }}$ sampling. The $3^{\text {rd }}$ Station recorded $>1600 / 100 \mathrm{ml}$ for all the samplings except for samplings 9 which recorded $>460$ MPN Index/100ml. Station 4 had the highest numbers of $>1600 \mathrm{MPN}$ Index $/ 100 \mathrm{ml}$ in samples 1, 2, 3, 4, 7 and 8, while the least number of coliforms, $1.100 / 100 \mathrm{ml}$ was recorded in sample 9.

In Station 5, the highest number of coliforms $>1600$ MPN Index $/ 100 \mathrm{ml}$ were recorded in samples $1,2,3,4,5$ and 6 , while the least number of coliforms $350 \mathrm{MPN}$ Index/100ml were recorded in samples 7 and 8 . These high counts were recorded in areas with domestic waste disposal, waste from poultry, untreated waste water from fish farm and disposal of untreated human waste. 
Table.1 Microbial Populations of the Water samples (CFU/ml)

\begin{tabular}{|c|c|c|c|c|c|c|c|}
\hline Stations & THB & TVC & TSSC & TCC & FCC & TPC & THF \\
\hline $\mathbf{1}$ & $5.32 \times 10^{6} \pm 0.63^{\mathrm{a}}$ & $2.39 \times 10^{3} \pm 1.8^{\mathrm{a}}$ & $1.68 \times 10^{4} \pm 1.84^{\mathrm{a}}$ & $2.02 \times 10^{4} \pm 1.48^{\mathrm{a}}$ & $1.89 \times 10^{4} \pm 1.56^{\mathrm{a}}$ & $1.10 \times 10^{2} \pm 1.00^{\mathrm{a}}$ & $3.3 \times 10 \pm 0.83^{\mathrm{a}}$ \\
\hline $\mathbf{2}$ & $8.41 \times 10^{6} \pm 0.49^{\mathrm{a}}$ & $6.79 \times 10^{3} \pm 1.75^{\mathrm{a}}$ & $2.02 \times 10^{4} \pm 1.45^{\mathrm{a}}$ & $5.31 \times 10^{4} \pm 1.59^{\mathrm{a}}$ & $7.80 \times 10^{4} \pm 0.83^{\mathrm{a}}$ & $2.87 \times 10^{2} \pm 1.23^{\mathrm{a}}$ & $4.4 \times 10 \pm 1.53^{\mathrm{a}}$ \\
\hline $\mathbf{3}$ & $9.59 \times 10^{6} \pm 0.52^{\mathrm{a}}$ & $8.10 \times 10^{3} \pm 2.07^{\mathrm{a}}$ & $2.37 \times 10^{4} \pm 0.71^{\mathrm{a}}$ & $6.10 \times 10^{4} \pm 1.65^{\mathrm{a}}$ & $7.55 \times 10^{4} \pm 0.76^{\mathrm{a}}$ & $2.45 \times 10^{2} \pm 1.31^{\mathrm{a}}$ & $1.11 \times 10^{2} \pm 1.4^{\mathrm{a}}$ \\
\hline $\mathbf{4}$ & $7.81 \times 10^{6} \pm 6.74^{\mathrm{a}}$ & $1.15 \times 10^{4} \pm 1.97^{\mathrm{a}}$ & $2.88 \times 10^{4} \pm 1.49^{\mathrm{a}}$ & $5.33 \times 10^{4} \pm 1.62^{\mathrm{a}}$ & $8.10 \times 10^{4} \pm 1.65^{\mathrm{a}}$ & $1.66 \times 10^{2} \pm 1.06 \mathrm{a}$ & $3.3 \times 10 \pm 0.83^{\mathrm{a}}$ \\
\hline $\mathbf{5}$ & $9.29 \times 10^{6} \pm 6.71^{\mathrm{a}}$ & $9.61 \times 10^{3} \pm 1.70^{\mathrm{a}}$ & $2.08 \times 10^{4} \pm 1.48^{\mathrm{a}}$ & $6.41 \times 10^{4} \pm 1.63^{\mathrm{a}}$ & $8.99 \times 10^{4} \pm 1.08^{\mathrm{a}}$ & $3.90 \times 10^{2} \pm 1.43^{\mathrm{a}}$ & $8.8 \times 10 \pm 1.89^{\mathrm{a}}$ \\
\hline
\end{tabular}

Station 1 is the control; Means with same alphabet across the column shows no significant difference ( $>0.05)$

Keys: THB: total heterotrophic bacteria, TVC: total Vibrio counts, TSSC: Salmonella-Shigella counts, TCC: Total coliform counts, TPC: Pseudomonas counts, THF; Total Heterotrophic Fungi

Fig.1 Map showing the different sampling points in Azumini-Odumaya stream in Rumuodamaya Community of Obio-Akpor LGA, Rivers State, Nigeria.
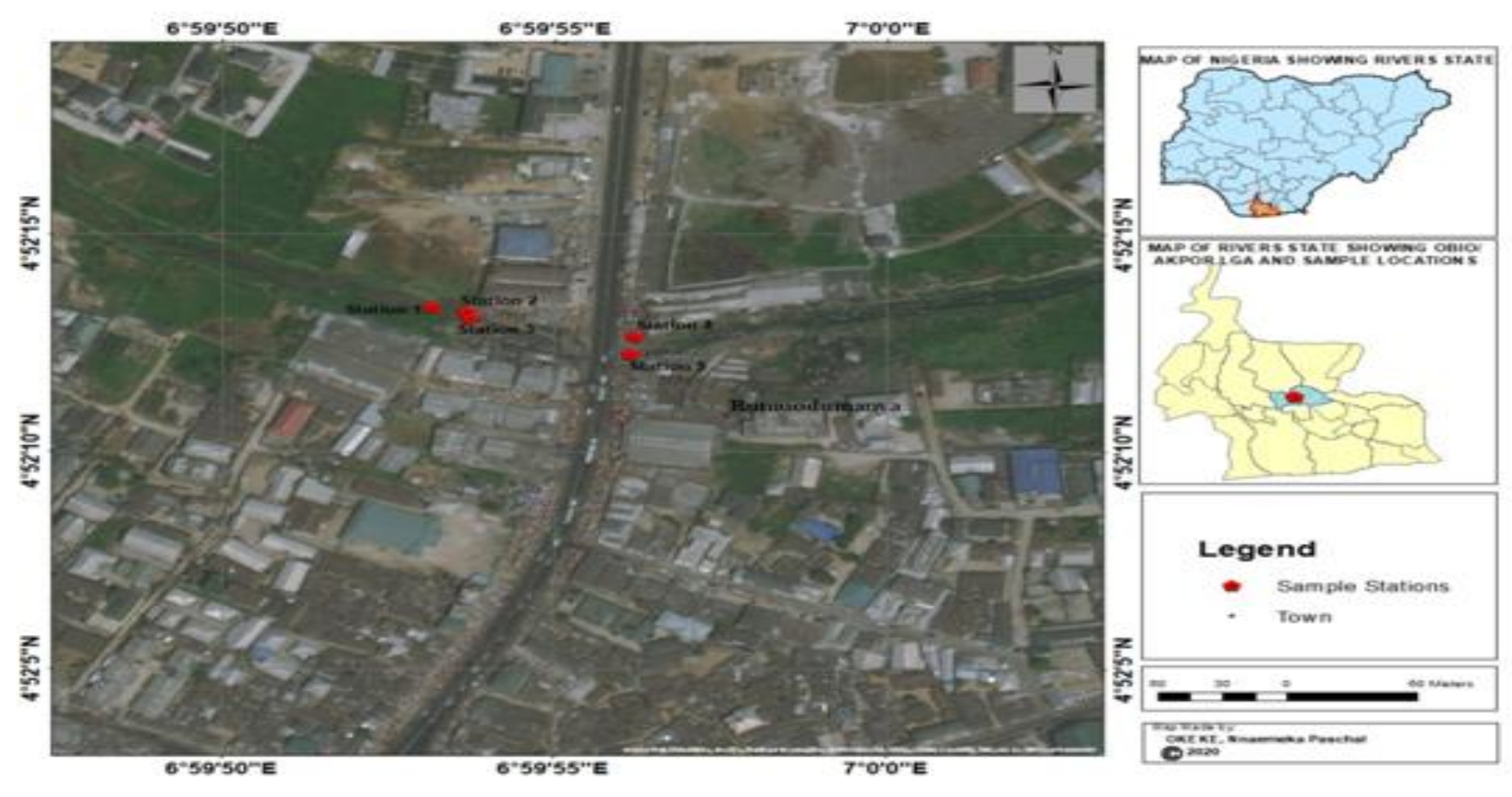
Table.2 Results of Faecal Coliform Using MPN (MPN Index/100ml)

\begin{tabular}{|c|c|c|c|c|c|c|c|c|c|}
\hline Stations & $\begin{array}{c}\mathbf{I}^{\text {st }} \\
\text { Sampling }\end{array}$ & $\begin{array}{c}\mathbf{2}^{\text {nd }} \\
\text { Sampling }\end{array}$ & $\begin{array}{c}\mathbf{3}^{\text {rd }} \\
\text { Sampling }\end{array}$ & $\mathbf{4}^{\text {th }}$ Sampling & $\begin{array}{c}\mathbf{5}^{\text {th }} \\
\text { Sampling }\end{array}$ & $\begin{array}{c}\mathbf{6}^{\text {th }} \\
\text { Sampling }\end{array}$ & $\begin{array}{c}\mathbf{7}^{\text {th }} \\
\text { Sampling }\end{array}$ & $\begin{array}{c}\mathbf{8}^{\text {th }} \\
\text { Sampling }\end{array}$ & $\begin{array}{c}\mathbf{9}^{\text {th }} \\
\text { Sampling }\end{array}$ \\
\hline $\mathbf{1}$ & $>1600$ & $>1600$ & 1600 & 34 & 34 & 1600 & $<2$ & 17 & 1600 \\
\hline $\mathbf{2}$ & $>1600$ & $>1600$ & 1600 & 34 & 70 & $>1600$ & 12 & 240 & 460 \\
\hline $\mathbf{3}$ & $>1600$ & $>1600$ & $>1600$ & $>1600$ & $>1600$ & $>1600$ & $>1600$ & $>1600$ & 460 \\
\hline $\mathbf{4}$ & $>1600$ & $>1600$ & $>1600$ & $>1600$ & 900 & 900 & 1600 & 1600 & 1600 \\
\hline $\mathbf{5}$ & $>1600$ & $>1600$ & $>1600$ & $>1600$ & $>1600$ & $>1600$ & 350 & 350 & 460 \\
\hline
\end{tabular}

Table.3 Distribution of Bacteria Isolated from the Various Stations

\begin{tabular}{|c|c|c|c|c|c|}
\hline Isolates & Station 1 & Station 2 & Station 3 & Station 4 & Station 5 \\
\hline Escherichia coli & + & + & + & + & + \\
\hline Pseudomonas spp & + & + & + & + & + \\
\hline Serratia spp & - & - & + & - & - \\
\hline Proteus spp & + & + & + & + & + \\
\hline Vibrio spp & + & + & + & + & + \\
\hline Shigella spp & + & + & + & + & + \\
\hline Salmonella spp & + & + & + & + & + \\
\hline Providencia spp & + & + & + & + & + \\
\hline Bacillus spp & + & + & + & + & + \\
\hline Klebsiella spp & + & + & + & + & + \\
\hline Staphylococcus spp & + & + & + & + & + \\
\hline Streptococus spp & + & + & + & + & + \\
\hline Enterobacter spp & - & - & + & - & - \\
\hline
\end{tabular}

Key: + represent present, - represent absent.

Fig.2 Frequency of occurrence of Bacterial isolates from the different water samples

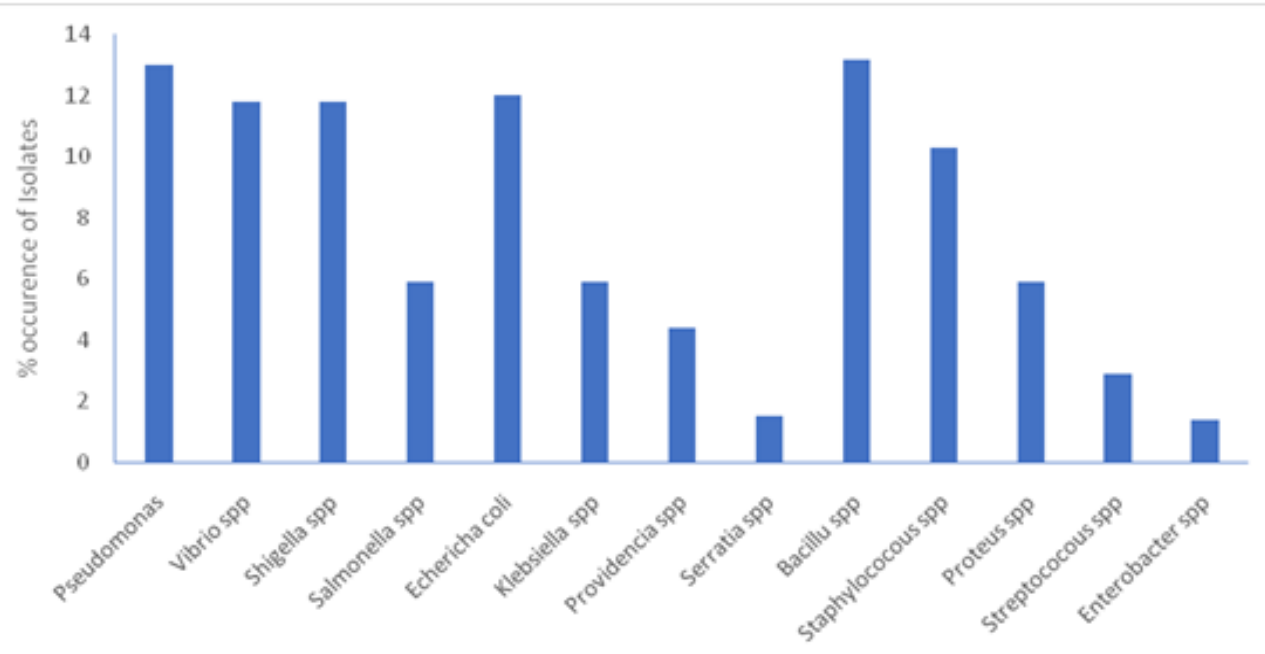


Fig.3 Frequency of occurrence of fungal isolates from the different water samples

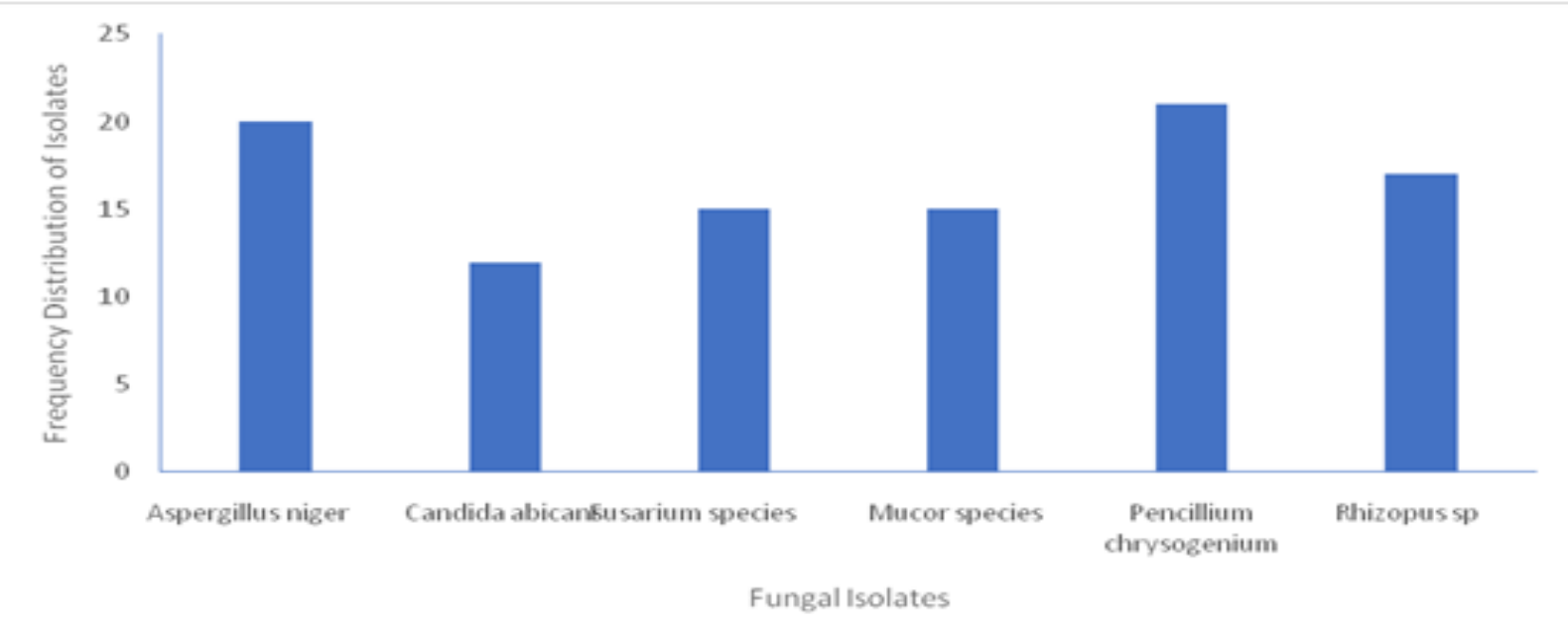

From a microbial perspective, the main public health concern associated with drinking water is enteric disease (EPA, 2003), because it is impractical to look for all known enteric pathogens that may contaminate drinking water, microbial safety is assessed through detection of indicators of faecal pollution (Leclerc et al., 2001). Microbial indicator of faecal pollution is an organism occurring in high numbers in human or animal faeces. If detected, it indicates potential faecal (human or animal) contamination of the water body or distribution system under investigation and the consequent potential presence of enteric pathogens (Prescott et al., 2002). These microbial indicators are generally not themselves human pathogens. Three main indicators of microbial safety of drinking water have been used: total heterotrophic bacteria, total coliform counts, and feacal coliform. The heterotrophic group of bacteria encompasses a broad range of bacteria that uses organic carbon sources to grow. The total coliform group is a large collection of bacteria that are mostly found in the environment. The feacal coliform group is a subset of the total coliform group that principally exists in faeces, while E. coli belongs to the faecal coliform group and is the only member that is specific to the intestinal tract of warm-blooded animals (Prescott et al., 2002). The presence of Pseudomonas sp identified in the AzuminiOdumaya stream may be of public health concerns as this organism has been reported to cause serious infections in immunocompromised persons. Concentrations of total coliforms, faecal coliforms, Vibrio, Shigella and Salmonella spp in Azumini-Odumaya Stream samples were high, indicating the extent of contamination of the water sources making it unsafe for food processing and drinking.

Most of the fungal isolates identified from this study are saprophytic in water, air and soil. These organisms have been implicated in various diseases; Aspergillus spp has been implicated in aspergillosis and onchomycosis, Fusarium spp is involved in onchomycosis and pneumonia. Mucor spp could cause opportunistic mycosis (Obire and Alali, 2015). Penicillium $\mathrm{sp}$ has been implicated in penicilliosis disease in humans.

In conclusion, the results of this study shows that the microbiological study of AzuminiOdumaya stream is highly polluted as a result of various anthropogenic activities going on 
along the stream bank, through dumping of domestic and human waste matter into the water body. The high counts of enteric organisms could pose serious danger if the water is used for recreation or other domestic purposes without prior treatment. Many of the bacterial isolates are potential pathogens which are associated with gastroenteritis and other forms of bacterial infections. These findings indicate public health hazards if the water is used for domestic purposes without any form of treatment. These sampling locations will continue to suffer contamination, except pollution control measures are put in place by the Local Government authority.

\section{References}

Adefemi, S. O. and Awokunmi, E. E. (2010). Determination of Physiochemical Parameters and Heavy Metals in Water Samples from Itaogbolu Area of Ondo State, Nigeria. African Journal of Environmental Science and Technology. 4(3), 145-148.

Amadi, E. N, Kiin-Kabari, D. B, Kpormon, L. B. and Robinson, V. K. K. (2014). Microbial flora and nutritional composition of adult Palm - Wine Beetle (Rhychophorus phoenicus). International journal of Current Microbiology and Applied Science; 3(11) 189-192.

Arain, M. B., Kazi, T.g., Jamali, M. K., Afridi, H. I., Baig, J. A., Jalbani, N. and Shah, A. Q. (2008). Evaluation of Physiochemical Parameters of Manchar Lake Water and Their Comparison with other Global Published Values, Pak. J. Anal. Environ. Chem.,9(2),101-109.

Barnett, H. L. and Hunter, B. B. (1992) Illustrated Genera of Imperfect Fungi. $3^{\text {rd }}$ ed. Burgess Publishing Company. Minnesota, USA.

Batram, J., Cotruvo, J., Exner, M., Fricker, C. and Glasmacher, A. (2003). Heterotrophic counts and drinkingwater safety: Significance of HPCs for water quality and human health. London, UK: IWA publishing.

Bellingham, K. (2012). Physicochemical Parameters of Natural Waters: Stevens Water Monitoring Systems. Http://Www.Stevenswater.Com/Index. Aspx 2(6): 141 -154.

Cheesbrough, M. (2005). District Laboratory Practice in Tropical Countries, Part. Cambridge University Press U.K 5580.

Douglas, S. I. (2015) Seasonal Variations of Fungi Found In Pond Water in the Niger Delta, Nigeria. International Research Journal of Natural and Applied Science. 2(2): $194-204$.

Douglas, S. I., and Isor, F. N. (2015). Bacteriological Investigation of pond water Quality from Ogoni Land, Nigeria. IORS Journal of Environmental Science, Toxicology and Food Technology (IOSR-JESTF); 9 (2): 36-41.

Douglas, S. I. and Amuzie, C. C. (2017) Microbiological Quality of Hoplobatrachus occipitalis (Amphibia, Anura) Used as Meat. International Journal of Current Microbiology \& Applied Sciences. 6(6): 3192-3200

EPA. (2003). US Environment Protection Agency Safe Drinking water Act. EPA 816-F-03-016.

Holt, G. J., Krieg, N. R., Sneath, P. H. A. Stanley, J. T., and Williams, S. T. (1994). Bergey's Manual of Determinative Bacteriology. $9^{\text {th }}$ edition. Holt, JD. Williams Wilkins CO. Baltimore.

Inane, B., Kinaci, C., Ozturk, I., Sevimali, M. F., Arikan, O. and Ozturk, M. (1998). Pollution Prevention and Restoration in the Golden Horn of Istanbul. Water, Science and Technology; 37 (8): 129- 
136.

Lawson, E. O. (2011). Physico-chemical parameters and Heavy Mental Contents of Water fromthe Mangrove Swamps of Lagos Lagoon, Lagos, Nigeria. Advances in BiologicalResearch,5(1): 821.

Leclerc, H., Mossel D. A, Edberg, S. C. and Struijk C. B. (2001). Advances in the Bacteriology ofthe coliform group: their suitability as markers of microbial water safety. Annu Rev Microbiol.55(1):20134.

Meybeck, M., Kimstach, V. and Helmer, R. (1996). Strategies for water quality assessment. In:Chapman, D. (Ed.) water quality assessment: A guide to the use of Biota, sediments and water in Environmental monitoring. 2nd edition. Chapman and Hall, London, pp 23-57.

Nduka, J. K., Orisakwe O. E and Ezenweke L. O. (2008). Some Physicochemical Parameters ofpotable Water Supply in Warri, Niger Delta Area of Nigeria.Scientific Research and Essay, 3(11),547-551.

Obire, O and Osigwe, I. S. (2016). Bacterial Quality of Spring Water in Ihitte/Uboma LGA of Imo State, Nigeria. Current Studies in Comparative Education, Science and Technology, 3(2):149-155.

Obire, O. and Aguda, M. (2012). Bacteria community of leachate from a Waste dump and adjacent stream in Nigeria. Journal of Applied Science and
Environmental management6(2): $71-$ 75

Obire, O. and Alali, A. (2015) Microbiology of Underground Water (Dug Wells) in Abua Central Area of Rivers State in Nigeria. Current Studies in Comparative Education, Science and Technology. 2(2): 246-258.

Obire, O., Nwaubeta, O. and Adue, S. B. N. (2002). Microbial community of a waste-dumpsite. Journal of Applied Science and Environmental Management; 6 (1):78-83.

Okpokwasili, G. C., Douglas, S. I. and Inengite, A. K. (2013). Seasonal variations of some physicochemical parameters of groundwater in crude oil flow stations. Journal of Environmental Science and Water Resources 2(1), 016 $-021$.

Prescott, L. M. Harley J. and Klein D. A. (2002). Microbiology Fifth Edition McGraw-Hill Companies. 185-204.

United Nation Department of Social and Economic Affairs (UNDSEA, 2001). Indicators of sustainable development: Guidelines and methodologies.2nd edition. United Nations, New York. 99p.

William, P. C. (1997). Environmental Science: A Global Concern. McGraw Hill: New York,; 445-446.

World Health Organization (WHO). (2009). Water Safety Plan Manual: Step by step risk management for drinking water suppliers.

\section{How to cite this article:}

Obire, Omokaro, Douglas, Salome Ibietela, and Chuku, Jennifer Ibuchim. 2021. Evaluation of the Impact of Anthropogenic Activities on the Microbiological Quality of Azumini Odumanya Stream, Port Harcourt, Nigeria. Int.J.Curr.Microbiol.App.Sci. 10(07): 143-153. doi: https://doi.org/10.20546/ijcmas.2021.1007.017 